\title{
CONTESTED TAX LIABILITIES AND THE ANNUAL ACCOUNTING CONCEPT-THE IAPANESE TRADING CO. APPLICATION
}

\section{INTRODUCTION}

A fundamental principle of federal income tax accounting is that a liability accrues and is deductible from gross income only in the year in which all events occur to fix both the fact and the amount of liability. ${ }^{1}$ A corollary of this rule is that a tax liability which ordinarily would accrue in a given year, if contested in that year, may not be deducted until final settlement of the litigation. ${ }^{2}$ Equally venerable is the "annual accounting concept" - the idea that income should be measured annually and not on the basis of completed transactions. ${ }^{3}$

In the recent case of Japanese Trading Co., ${ }^{4}$ the Tax Court of the United States upheld the right of a taxpayer to deduct as a liability customs duties which had not yet been assessed or paid, and which were contested by the taxpayer in a later year. It is the thesis of this Comment that the considerations underlying the annual accounting concept-relied on by the Tax Court-are inapposite in this context, and that the policies underlying the all events test call for a different result. A brief examination of the development of the two doctrines, and their relationship to pertinent sections of the Internal Revenue Code of 1954, is helpful in analyzing their effect on the facts of Japanese Trading Co.

\section{A. The All Events Test}

The rule indicating the year in which a deduction should be taken is given in section 461 (a) of the Code, which provides that allowable deductions "shall be taken for the year which is the proper taxable year under the method of accounting used in computing taxable income." This "method of accounting used in computing taxable income" is in turn defined in section 446 (a) as that method "on the basis of which the taxpayer regularly computes his income in keeping his books." However, if the taxpayer's method does not "clearly reflect income," the Commissioner of Internal Revenue has authority under section

1 United States v. Consolidated Edison Co., 366 U.S. 380, 385 (1961).

2 Dixie Pine Products Co. v. Commissioner, 320 U.S. 516 (1944).

3 Burnet v. Sanford \& Brooks Co., 282 U.S. 359 (1931).

425 CCH Tax Ct. Mem. 441 (1966). 
446(b) to substitute a method of accounting which does clearly reflect income. $^{5}$

It remained for the courts to establish more specific standards for the proper time of taking a deduction. In United States $v$. Anderson, ${ }^{6}$ the Supreme Court dealt with a deficiency assessment by the Commissioner based on a statutory provision comparable to section 461. ${ }^{7}$ The taxpayer, an accrual-method manufacturer, paid a munitions tax in 1917 which was assessed in 1917 on goods manufactured in 1916. He then deducted this payment from his income for 1917, on the theory that "a tax does not accrue until it becomes due and payable." The Court rejected this argument.

In a technical legal sense it may be argued that a tax does not accrue until it has been assessed and becomes due; but it is also true that in advance of the assessment of a tax, all the events may occur which fix the amount of the tax and the liability of the taxpayer to pay it. .. . In the economic and bookkeeping sense with which the statute and Treasury decision were concerned, the taxes had accrued. ${ }^{8}$

The Court's decision was based on accounting theory. Under the accrual method of accounting, an attempt is made to match expenses with the income they help to produce. Accordingly, where possible, such income and expenses should be recognized in the same accounting period, since recognizing the expenses in one period and the income in another would distort the net income of both. The Court noted:

5 Section 446 (b) gives this power to the Secretary of the Treasury or his delegate. The Secretary's delegate is the Commissioner of Internal Revenue. Treas. Reg. $\S 1.446-1$ (b) (1) (1957).

6269 U.S. 422 (1926).

7 Revenue Act of 1916, ch. 463, § 13(d), 39 Stat. 771.

8269 U.S. at 441. (Emphasis added.) The Court implied that both the fact and the amount of a liability must be fixed before it can be deducted. The present rule is that a liability is deductible when the fact of liability is fixed and the amount of liability is determinable with reasonable accuracy. Anderson-Clayton Securities Corp., 35 B.T.A. 795, 803 (1937) ; Treas. Reg. $\$ 1.461-1$ (a) (2) (1957). Deductions for estimated future expenses are allowed, in certain specified circumstances, by a few sections of the Code and Regulations. INT. REv. CODE of 1954, $\S 166$ (c) (reserve for bad debts) ; Treas. Reg. \$1.451-4 (1957) (value of merchandise for which trading stamps will be redeemed). Compare Schuessler v. Commissioner, 230 F.2d 722 (5th Cir. 1956) (fixed future costs of turning furnace off and on may be deducted in year of sale of furnace where this service was part of the selling price of the furnace) with Paul H. Travis, 47 T.C. No. 50 (Feb. 20, 1967) (amounts due and payable for dance lessons must be taken into income whether lessons given yet or not; reasonable addition can be made to reserve for bad debts for amounts due which are found to be uncollectible). However, these sections appear to be exceptions to the general rule. Section 462 of the 1954 Code, 68A Stat. 158 (1954), allowed the deduction of reasonable yearly additions to various reserves for estimated expenses. It was repealed, 69 Stat. 134 (1955), less than a year after enacted, on the ground that it and its companion provision $\$ 452$ (allowing prepaid income to be spread over an appropriate number of years) would reduce revenues by as much as several billion dollars during the transitional period, when taxpayers would continue to deduct the costs of servicing old contracts, in addition to deducting estimated expenses deferring recognition of prepayments. BitTker, Federal INCOME, Estate AND GIFT TAXation 806 (3d ed. 1964). No new legislation along similar lines has been proposed. 
[A]ppellee's true income for the year 1916 could not have been determined without deducting from its gross income for the year the total cost and expenses attributable to the production of that income during the year. ${ }^{\text {? }}$

Thus, Anderson introduced the all events test into federal tax accounting. The test was first applied by the Supreme Court to the area of contested liabilities ${ }^{10}$ in Dixie Pine Products Co. v. Commissioner. ${ }^{11}$ In that case, the accrual-method taxpayer used as a cleaning fluid a substance on which Mississippi assessed a gasoline tax. ${ }^{12}$ The taxpayer started a proceeding in state court to restrain future collections of the tax on the ground that the substance in question was not gasoline. While the state action was pending; the taxpayer accrued the unpaid and contested state tax as a liability and deducted it on its federal income tax return. The Supreme Court pointed out that the taxpayer's attempts both to contest and accrue a tax as a fixed and certain liability were inconsistent. While the amount of the alleged liability was certain, the fact of liability was clearly in doubt, and depended on the outcome of the litigation. The Court held that the accrual of the tax, at least for income tax purposes, must await final court adjudication, ${ }^{13}$ which presumably is the last of the events "fixing" liability. ${ }^{14}$

Carried to its logical extreme, the all events test would require that even contested liabilities which had been paid should not be deducted until finally adjudicated. The Supreme Court so held in United States v. Consolidated Edison Co., ${ }^{15}$ overruling the previous Treasury position. ${ }^{16}$ But in 1964, Congress enacted section 461(f)

9269 U.S. at 440 . While Anderson involved a tax liability, the rule of the case has been made applicable by the Regulations to all expenses. See Treas. Reg. $\$ 1.461-1$ (a) (2) (1957), as amended, T.D. 6772, 1964-2 Cum. Bulr. 121, 122.

10 The test also forbids deductions of liabilities which are not contested but merely contingent. See Goebel Brewing Co., 43 T.C. 8 (1964).

11320 U.S. 516.

12 State taxes were then deductible under Int. Rev. Code of 1939 , ch. 1, $\$ 23(c)$ (d), 53 Stat. 12. The present provision is Int. Rev. CoDE of 1954, $\$ 164$.

${ }^{13}$ Adjudication is final when the time for appeal has elapsed. Cf. Lasky v. Commissioner, 235 F.2d 97 (9th Cir. 1956), aff'd per curian, 352 U.S. 1027 (1957).

14 It is possible to set up a system which would allow taxpayers to deduct all expenses pertaining to the current accounting period, whether fixed or not, then allow adjustments in later accounting periods in which the amount of expense becomes fixed and definite. This method is used in England. See Southern Ry. of Peru, Ltd. v. Owen, [1956] 2 All E.R. 728 (H.L.), discussed in Freeman, Tax Accrual Accounting for Contested Items, 56 Mich. L. Rev. 727, $744-45$ (1958). But the United States system has evolved differently, and a change now would involve an enormous, albeit temporary, loss of income. See discussion of the repeal of $\$ 462$ of the 1954 Code in note 8 , sipra.

15366 U.S. 380 (1961).

16 In G.C.M. 25298, 1947-2 Cunr. Bull. 39, the Commissioner accepted the position of the Court of Claims that "accrual . . precedes payment and does not survive it." Chestnut Securities Co. v. United States, 104 Ct. Cl. 489, 494-95, 62 F. Supp. 574,576 (1945). Hence, a liability which had been paid was held to be properly 
which reinstated the old rule..$^{17}$ Thus, a taxpayer who is actually out of pocket the amount of the liability is entitled to tax relief, even though his payment may eventually be refunded. ${ }^{18}$

In summary, where a liability is contested but not paid, the all events test calls for deduction of the liability in the year in which it becomes fixed. Where the liability, although contested, has been paid, a deduction is allowed in the year of payment. Thus, a taxpayer who has not paid, and may never have to pay, is not entitled to a deduction until his obligation becomes fixed and certain.

\section{B. The Annual Accounting Concept}

The annual accounting concept received its classic statement in Burnet v. Sanford \& Brooks Co. ${ }^{19}$ In that case, the taxpayer was a dredging company which had incurred large expenses ${ }^{20}$ performing a contract for the federal government. During 1913, 1915 and 1916,

accruable and deductible for tax purposes in the year of payment, even though payment was made under protest and an action for a refund promptly brought. Ibid. The situation was confused by the promulgation of MIM. 6444, 1949-2 CUM. BuLL. 11, which contradicted G.C.M. 25298 in holding that "where payment of a tax is required as a prerequisite for further appeal, such payment is not to be regarded as a payment of a demanded tax deficiency." In other words, since the payment was not in settlement of a suit, the payment was not deductible. The earlier ruling had held that taxes paid under protest were to be deducted in the year of payment. It seems diffcult, as a practical matter, to draw a viable line between payments made under protest with subsequent litigation for a refund, and payments made as a prerequisite for appeal.

17 INr. Rev. CoDE of 1954, §461(f) provides:

If-

(1) the taxpayer contests an asserted liability,

(2) the taxpayer transfers money or other property to provide for the satisfaction of the asserted liability,

(3) the contest with respect to the asserted liability exists after the time of the transfer, and

(4) but for the fact that the asserted liability is contested, a deduction would be allowed for the taxable year of the transfer (or for an earlier taxable year),

then the deduction shall be allowed for the taxable year of the transfer.

Thus, the provision allows the deduction both of taxes paid, with subsequent litigation for a refund, and taxes paid as a prerequisite for appeal.

This language has been interpreted by a revenue agent as compelling the result that a tax accrued in one year and contested in a later year is deductible only when paid, or when a suitable "transfer" is made. Harris, Tax Deductibility of Contested Taxes and Legal Expenses, Management Accounting, April, 1966, p. 36. This result is the opposite of that reached by the Tax Court in Japanese Trading Co. However, the interpretation seems strained. The provision, passed to overrule the result in United States v. Consolidated Edison Co., 336 U.S. 380 (1961), see text accompanying notes 15-17 sipra, would not seem to affect the situation where the tax is already deductible before the transfer is made. Its purpose was only to give a deduction to a taxpayer who is out of pocket the amount of the transfer, even if ultimate liability has not yet been fixed.

18 Were the payment ultimately refunded, the taxpayer would take the refund into income in the year of repayment. See S. REP. No. 830, 88th Cong., 2d Sess. 101 (1964).

19282 U.S. 359 (1931).

20 It was held that these were current expenses and not capital investments, "the cost of which, if converted, must first be restored from the proceeds before there is a gain taxable as income." Id. at 363-64. 
the expenses exceeded payments on the contract, and the taxpayer reported net losses on its income tax returns. The contract was terminated before completion, and the taxpayer successfully recovered its expenses in litigation ending in 1920. The Commissioner contended that this recovery should be included in the taxpayer's gross income for 1920. The taxpayer argued that the Sixteenth Amendment and the applicable Revenue Act ${ }^{21}$ contemplated a tax on gain or profit, and that there was no gain or profit on the entire transaction. Nonetheless, the Supreme Court held that the Revenue Act contemplated, and the Sixteenth Amendment allowed, the assessment of taxes "on the basis of annual returns showing the net result of all the taxpayer's transactions during a fixed accounting period . . . ." 22 The Court noted that the transactional approach would create impossible administrative problems, since the tax might have to be postponed for an indefinite period in order to determine whether there would be a net gain or a net loss. ${ }^{23}$

It is the essence of any system of taxation that it should produce revenue ascertainable, and payable to the government, at regular intervals. Only by such a system is it practicable to produce a regular flow of income and apply methods of accounting, assessment, and collection capable of practical operation. $^{24}$

The Court held that, under the circumstances, the expenses of 1913 , 1915 and 1916 should not be carried forward and matched against the income of 1920. Stated more broadly, the holding was that income or expenses of one year should not, except in ways allowed by the

21 Revenue Act of 1918, ch. 18, $\S 230,232,234,40$ Stat. 1075, 1077 (1919).

22282 U.S. at 363.

23 A slightly different sort of transactional approach was rejected in Security Flour Mills Co. v. Commissioner, 321 U.S. 281 (1944). There the taxpayer contested the constitutionality of a processing tax. The court ordered the tax to be paid into a depository pendente lite. The taxpayer deposited $\$ 93,000$ in 1935 and treated it as a cost of production in setting prices. In 1936, the tax was declared unconstitutional, and the money returned to the taxpayer, who refunded some of it to its customers for purposes of good will. The taxpayer attempted to deduct the refunds in 1935 . It argued that under Int. Rev. Code of 1939, ch. $1, \$ 43,53$ Stat. 24 (now $\$ \$ 461$ (a), 446 (b) ) deductions or credits were to be taken in the year paid or accrued "unless in order to clearly reflect the income the deductions or credits were to be taken as of a different period," and that to report gross sales in 1935 and report the customer refunds in later years would distort its net income for 1935 and other years. (Dixie Pine, just decided, foreclosed the taxpayer from arguing that the full $\$ 93,000$ should be deducted in 1935.) The Supreme Court dismissed the argument.

In short, the petitioner's position is that the Commissioner and the Board of

Tax Appeals are authorized and required to make exceptions to the general rule of accounting by annual periods wherever, upon analysis of any transaction, it is found that it would be unjust or unfair not to isolate the transaction and treat it on the basis of the long term result. We think the position is not maintainable.

321 U.S. at 285.

24282 U.S. at 365. 
Code, ${ }^{25}$ affect the measurement of net gain or loss in another year. In effect, the holding was the same as that of Anderson, where a munitions tax accruing in 1916 was held not deductible in 1917. In Dixie Pine and other contested tax cases, the same reasoning is applied to future expenses; i.e., an expense belonging to some future periodthe one in which the contest is settled-should not be brought into the current period.

\section{Japanese Trading Co.}

The facts of Japanese Trading $\mathrm{Co}^{26}$ provide an interesting opportunity for application of these doctrines. In this case, A. Zerkowitz \& Co., an accrual basis taxpayer, imported in 1958 and 1959 a quantity of shoes, some with uppers partially made of leather, others with uppers made of cloth. ${ }^{27}$ The shoes with partial leather uppers were subject to duty at twenty per cent ad valorem, unless they were "men's, youths', or boys'," in which case the rate was ten per cent. ${ }^{28}$ Zerkowitz declared on a customs form that the shoes were for men, youths and boys, and paid a duty at the ten per cent rate. At the same time, it posted a bond ${ }^{29}$ guaranteeing payment of any other duties subsequently found to be due, a prerequisite to obtaining release of the goods from Customs. ${ }^{30}$ Nonetheless, Zerkowitz accrued the duty on its books at the twenty per cent rate, ${ }^{31}$ and deducted both the ten per cent which

25 The Court pointed out that the taxpayer had failed to take advantage of two remedies available to it under the existing tax statute and regulations. Id. at 366 . The regulations allowed a taxpayer reporting income from a long term contract either to report all receipts and all expenditures connected with the contract in the year it was completed (completed contract method), or to report in each year the percentage of the estimated profit on the contract corresponding to the percentage of the total estimated expenditures incurred in the taxable year (percentage of completion method). The current regulation is Treas. Reg. $\$ 1.451-3$ (1957).

The Court also suggested that the taxpayer could have used the accrual method, allowed by Revenue Act of 1918, ch. $18, \$ 212$ (b), 40 Stat. 1064-65 (1919). The present provision is INT. Rev. CoDe of 1954, §446(c) (2).

2625 CCH Tax Ct. Mem. 441 (1966).

27 Id. at $442,443$.

28 Id. at 442.

29 Brief for Petitioners, p. 19. It should be noted that the posting of bond for any additional customs duties that might be levied is not sufficient to constitute a "transfer" under INT. REv. CoDE of 1954, § 461 (f), as interpreted by the Commissioner in Treas. Reg. $\$ 1.461-2$ (c) (1). Presumably this is so because the posting of a bond does not put the taxpayer out of pocket the amount of the liability or the face value of the bond.

$3025 \mathrm{CCH}$ Tax Ct. Mem. at 442 . The procedure followed by the customs officials is as follows :

(1) At the port of entry, the importer declares the value of the goods imported and the rate at which they are to be taxed, and pays the resulting duty. He also posts bond for any additional duties which might be found due on the imported goods. The goods are then released to him.

(2) At a later time, customs officials review the declaration forms to determine whether the goods were properly valued, and whether the correct rate of duty was used; the correct amount of duty is thus computed. The importer is then notified of any proposed changes and given an opportunity to appeal the additional assessment. Ibid.

31 Ibid. 
had been paid and the additional ten per cent on its federal income tax returns for 1958 and 1959. ${ }^{32}$ The shoes with cloth uppers were treated in a similar manner-a low value was declared for computing the duty paid, but a higher duty, based on a higher valuation, was deducted on the tax return. ${ }^{33}$ Over a year later, customs officials reviewed the declaration forms and assessed additional duties, based on the higher rate and valuation. Zerkowitz contested these increases in rate and in value in the United States Customs Court and lost. ${ }^{34}$

The unpaid accrued duties on shoes imported by Zerkowitz in 1958 amounted to $\$ 65,361.40$. This sum was charged against sales of these goods as current cost of goods sold. ${ }^{35}$ The unpaid accrued duties on 1959 imports amounted to $\$ 345,385.27$, making a total of $\$ 410,746.67$ for 1958 and 1959 , the two taxable years before the court. $^{36}$ Of the unpaid duties for $1959, \$ 95,015.49$ was invoiced to Overseas Shoe Corp., a wholesale distributor for New York City, and $\$ 50,149.94$ to Japanese Trading Co., Ltd., a wholesale distributor for the rest of the United States, as the amounts of unpaid import duties on goods sold by Zerkowitz to Overseas and Japanese respectively. Both Overseas and Japanese accrued these amounts on their books as accounts payable to Zerkowitz and deducted them on their federal income tax returns for 1959 by increasing cost of goods sold. ${ }^{37}$

While neither the 90 day letter nor the Tax Court opinion make clear the Commissioner's theories in disallowing the respective deductions, reasonable speculation is possible. In denying the deductions to Overseas and Japanese, the Commissioner must have been saying that Zerkowitz had agreed to refund these amounts to Overseas and Japanese respectively if Zerkowitz did not have to pay the additional duties. Thus, the liabilities of Japanese and Overseas to Zerkowitz were contingent on the result of Zerkowitz' litigation, and were not fixed sufficiently to be deducted. ${ }^{38}$ With regard to Zerkowitz' deduc-

32 Id. at 443.

33 Shoes with cloth uppers are valued for the purpose of computing the customs duty by comparing them with the market price of similar shoes made by United States Rubber Co. Ibid. Zerkowitz declared a value based on its cost from Far East suppliers or on the market prices of U.S. manufacturers who set their prices lower than the prices of comparable shoes made by United States Rubber Co. Again, Zerkowitz accrued and deducted the duty paid plus an additional duty, based on the difference between the value it had declared and the selling price of United States Rubber Co.'s shoes. Ibid.

34 A. Zerkowitz \& Co. v. United States, 54 Cust. Ct. 151 (1965) ; A. Zerkowitz $\&$ Co. v. United States, 55 Cust. Ct. 643 (1965).

$3525 \mathrm{CCH}$ Tax Ct. Mem. at 443.

36 Some of the duties based on the higher rate were paid after 1959, ibid., probably as a prerequisite to appeal. See $i d$, at 442 . Others remained unpaid at the time of the Tax Court's decision. Id. at 443.

37 Ibid.

38 Presumably, Zerkowitz had sold the other imports without a refund agreement and thus those receivables were includible in his income. Absent a refund agreement, of course, the payables would be fixed and not subject to the contingency of the success or failure of Zerkowitz' actions in the Customs Court. They would thus be properly deductible by the purchaser and includible in gross income by Zerkowitz. 
tions, the Commissioner seems to have reasoned as follows: the $\$ 65,361.40$ charged against cost of goods sold in 1958 was totally disallowed; similarly, the $\$ 345,385.27$ charged against cost of goods sold in 1959 was disallowed; however, for 1959 an additional adjustment was necessary. Since Zerkowitz had presumably included the $\$ 145,155.43$ invoiced to Japanese and Overseas in its gross receipts, the existence of the refund agreement required that Zerkowitz' 1959 income be reduced by that amount. Thus, for 1959 the Commissioner increased Zerkowitz' net taxable income by the difference between $\$ 345,385.27$ and $\$ 145,155.43$, or $\$ 200,219.84$.

The Commissioner disallowed the deductions claimed by Zerkowitz, Japanese and Overseas, saying that they were " 'not paid but contested." "39 The taxpayer pointed out in reply that no active contest was begun, in each instance, until after the taxable year in question. ${ }^{40}$

The problems of defining a contest and determining whether a contest exists had previously been considered by the Tax Court in several cases. In Great Island Holding Corp. ${ }^{41}$ the Tax Court noted:

We do not agree with petitioner's contention that the "contested tax" rule is applicable only in cases where the dispute has been carried to the courts. In our view, it is sufficient if the taxpayer does not accrue the items on its books and denies liability therefore. ${ }^{42}$

What constitutes a denial of liability? In the Regulations, the Commissioner states that an "affirmative act denying the validity or accuracy" of an asserted liability is sufficient to start a contest, and gives as an example the lodging of a protest under local law. ${ }^{43}$ The Tax Court has gone further. In Gunderson Bros. Eng'r Corp. ${ }^{44}$ a taxpayer claimed a large deduction on its state franchise tax return. Two years later, the taxpayer amended the state return, eliminating the deduction, and sought to deduct the additional state tax for federal income tax purposes in the earlier year. The Tax Court held that the claiming of a deduction on the state tax return constituted a denial of liability for further state tax. In conjunction with a failure to accrue the additional tax, this denial, under the Great Island Holding Corp. definition, constituted the commencement of a contest which lasted until the taxpayer amended its state tax return and eliminated the deduction. Hence, the taxpayer could deduct the extra state taxes

3925 CCH Tax Ct. Mem. at 444.

40 Brief for Petitioners, pp. 16-17.

415 T.C. 150 (1945), followed in Southwest Exploration Co. v. Riddell, 232 F. Supp. 13 (S.D. Cal.), aff'd, 362 F.2d 833 (9th Cir. 1966).

425 T.C. at 160.

43 Treas. Reg. $\$ 1.461-2(\mathrm{~b})(2)$ (1964).

4416 T.C. 118 (1951). 
on its federal income tax return only in the year in which it ended the contest by amending its state tax return. ${ }^{45}$

On the other hand, in Dravo Corp. v. United States, ${ }^{46}$ the Court of Claims rejected the argument that the filing of a return admitting liability for a stated amount of tax constituted a denial of further liability. The court said that the only basis for extending the concept of contest to such a situation would be the "taxpayer's subjective motive as to what was intended when a return was filed," 47 which would be a difficult and impractical standard for the administration of tax law.

Clearly the act of declaring liability for a stated amount of tax is an ambiguous one. The taxpayer may fully intend to pay more tax without a contest if more than the amount reported is assessed. ${ }^{48}$ His act, without more, is neither an admission nor a denial of liability for more tax. ${ }^{49}$ On the other hand, the claim of a deduction is arguably a more affirmative act, unambiguously denying liability for tax on the gross income cancelled out by the deduction. For example, in Gunderson, the claim of a deduction on a state tax return represented a denial of liability of the additional state taxes assessed when the deduction was disallowed by the state taxing authority. While this distinction is by no means compelling, ${ }^{50}$ Japanese Trading Co. is distinguishable from both Gunderson and Great Island Holding Corp. because: (1) Zerkowitz accrued the additional taxes (duties) on its books, and (2) Zerkowitz claimed no deduction on the customs declaration forms, but merely declared a value and rate of duty, producing a stated amount of tax.

Perhaps because of these distinctions, the Commissioner did not argue in his brief before the Tax Court, as he did in his deficiency notice, that the taxpayer had contested the additional duties in the year of accrual. He did contend, however, that the liability for the undeclared, unpaid and unassessed duties had not become fixed, either in fact or amount, in the years of importation, and consequently was improperly accrued and deducted in those years.

This contention seemed directly to contradict an earlier case, Keller-Dorian Corp., ${ }^{51}$ on which Zerkowitz had relied in preparing its income tax returns. ${ }^{52}$ In Keller-Dorian, the accrual-method tax-

45 Accord, Agency of Canadian Car and Foundry Co., 39 T.C. 15 (1962).

46348 F.2d 542 (Ct. Cl. 1965).

47 Id. at 545 .

48 Ibid.

49 The taxpayer argued in its brief that its accrual and deduction of the additional duties constituted an admission of them to the Treasury Department in general and the Customs Bureau in particular. Reply Brief for Petitioners, pp. 3-4. This argument was not mentioned in the opinion of either the Tax Court or the Customs Court.

50 A taxpayer may claim a deduction intending to withdraw it without a contest if it is disallowed.

514 CCH Tax Ct. Mem. 558 (1945), aff'd, 153 F.2d 1006 (2d Cir. 1946).

52 See letter of April 20,1960, to Zerkowitz from its tax attorney, reprinted in part in $25 \mathrm{CCH}$ Tax Ct. Mem. at 443-44. The Keller-Doriais case created a dilemma 
payer imported goods during 1935-1940, paying duties at the time of importation. ${ }^{53}$ In 1940 and 1941, Customs officials requested KellerDorian to reappraise its imports from 1935 to 1940 and, as a result, $\$ 7,695.35$ in additional duties were accrued and paid in 1940 and 1941. The Commissioner disallowed deductions of these sums in those years. The taxpayer argued that Dixie Pine required that the deductions for the additional duties be postponed until fixed, ${ }^{54}$ but the Tax Court pointed out that "it does not appear that petitioner disputed or questioned its liability to pay the additional duties" and, in fact, they were promptly paid. ${ }^{55}$ The court held that liability for the additional duties became fixed in the years of importation. Its expressed reason for so holding was the taxpayer's failure to show that all events had not occurred in those years, and to show that the additional duties were not merely to correct errors in the taxpayer's original computations of the duties.

Thus, the Tax Court's decision confined itself to the narrow fact situation before it - a taxpayer who offered no excuse why he should not have paid the additional duties in the year of importation. ${ }^{56}$ In Keller-Dorian there was no contest of the additional liability either in the year of importation or in subsequent years. Subsequent events

for Zerkowitz (which was located in New York City, and thus bound by this Second Circuit decision). On the one hand, if customs officials assessed higher duties in years subsequent to the year of importation, it might lose deductions for them under Keller-Dorian if it did not accrue and deduct the additional duties in the year of importation. On the other hand, such deductions might be disallowed as contested under Dixie Pine Products Co. See id. at 445.

53 The normal rule is that duties become due on imported goods in the year of importation. United States v. Sandoz Chem. Works, 14 C.C.P.A. 21 (1926); 19 C.F.R. $\$ 8.1$ (a) (1966).

54 Apparently, the statute of limitations had run on the earlier years, so the taxpayer would lose his deductions for the additional duties altogether if the court did not permit them to be taken in 1940 and 1941. Cf. Int. Rev. Code of 1939, ch. 1, $\S 322$ (b) (1), 53 Stat. 91.

$554 \mathrm{CCH}$ Tax Ct. Mem. at 560.

56 The Second Circuit affirmed, 153 F.2d 1006 (1946), relying on its earlier decision in Uncasville Mfg. Co. v. Commissioner, 55 F.2d 893 (2d Cir.), cert. denied, 286 U.S. 545 (1932). In Uncasville, the taxpayer paid a state income tax for 1918, and deducted it on its federal income tax return for the same year. Later, the Commissioner increased the taxpayer's income for 1918. The state income tax increased proportionately, because it was calculated on income measured by federal tax standards. The taxpayer argued that it should be able to deduct the additional state tax in 1918 . The court agreed, holding, in an opinion by Judge Learned Hand, that the state tax was "unknown, not unknowable on December 31, 1918." 55 F.2d at 895.

In its opinion in Keller-Dorian, the Second Circuit cited Untcasville as authority for the proposition that a taxpayer may not take advantage of his own error in an earlier year to claim a deduction in a later year in which the error is discovered. 153 F.2d at 1007. Actually, the taxpayer in Uncasville contested the Commissioner's increase in its income. Thus, it sought to deduct additional state taxes which were contingent on the result of its suit. This is precisely what the Supreme Court later ruled that the Dixie Pine Products Corp. could not do, implicitly overruling Uncasville on this issue.

Moreover, Judge Hand's test of "unknown, not unknowable" is unrealistic in assuming that the taxpayer can predict the results of litigation of questions of either fact or law. A more modern and realistic approach was taken in Baltimore Transfer Co. v. Commissioner, 8 T.C. 1 (1947). There, the court noted: "Changes in law and in official interpretation of law, particularly if not reasonably expectable, must . . . be regarded as independent operative facts for accounting purposes." Id. at 9. 
resolved the ambiguity of the declaration of a stated amount of tax in Keller-Dorian, and proved that it did not signify the denial of any larger duty; liability for the additional duties was fixed, if it was knowable in the earlier year, since it was paid without protest. ${ }^{\mathbf{5 7}}$ The only contest in Keller-Dorian concerned the year in which the deductions for the additional duties should be taken.

Subsequent events showed exactly the opposite in Japanese Trading Co. - that if larger duties had been imposed in the year of importation, they would presumably have been contested and the deductions for the additional duties lost for that year. The Tax Court, however, pointed out that there had been no contest in the year of importation, and viewed the existence of a subsequent contest as "immaterial and irrelevant," citing Burnet $v$. Sanford \& Brooks Co. ${ }^{58}$

As noted above, ${ }^{59}$ Sanford \& Brooks held that Congress could measure income in annual segments for tax purposes. The decision was based on considerations resulting from the administrative difficulties of the transactional approach, and the government's need for a regular and dependable source of income. Waiting for a transaction to be completed before imposing a tax could create great administrative problems of record-keeping and surveillance, since a transaction could continue for an indefinite period of time. Moreover, the transactional approach would deprive the government of a regular and dependable source of income, since many more transactions might be completed in some years than in others. But these policies are inapplicable to the question of whether subsequent events may be considered in determining whether a liability is fixed. The burdens of administering such an approach would be much less than those posed by the transactional approach, since the three year statute of limitations on reassessing taxes would limit the required amount of surveillance and recordkeeping. This three year cut-off would also satisfy the second concern of the Court in Sanford \& Brooks by keeping government revenues regular and dependable.

On a conceptual level, it is one thing to say that the Government may look at an event in year two to determine whether a liability was fixed in year one; it is quite another thing to say that an indefinite period of time must be examined to determine whether a taxpayer had income at all. Also-to the extent that modern tax law defines income as unborrowed money available to the taxpayer free from restriction on use-the taxation of Zerkowitz' receipts should not be reduced just because the events of future years may call for an offsetting expenditure. Clearly, then, the policies of the annual accounting concept do not forbid the consideration of the events of other years in determining whether a liability was fixed.

50 See text accompanying notes 19-25, supra. 
The Tax Court itself has considered the effect of the events of other years on the years before it. In Dobson $v$. Commissioner, ${ }^{60}$ the Supreme Court upheld the Tax Court's inquiry into years previous to the ones before it in order to learn whether capital losses deducted in the earlier years had produced a tax benefit. ${ }^{61}$ Similarly, in Goebel Brevering Co. ${ }^{62}$ the taxpayer cancelled a contract on the last day of its fiscal year, and deducted $\$ 600,000$ which was due under the contract. Over the taxpayer's objection, the government was allowed to prove that subsequent negotiation reduced the liability to $\$ 275,000$. The court held that evidence of the negotiations was admissible to show the position of the parties as of the end of the fiscal year and that, at that time, the taxpayer's obligation was not fixed.

A sensible approach, from which the Tax Court departs in Japanese Trading Co., would require a taxpayer who accrues and deducts a liability in one year, and contests it in a subsequent year, to amend his return for the first year and eliminate the deduction, ${ }^{63}$ if the statute of limitations has not yet run. ${ }^{64}$ However, the statute of limitations should not pose a serious problem to the Commissioner. It allows him three years from the date of the filing of a given return to assess the deficiencies on that return. If customs officials, who are also part of the Treasury Department, act promptly to review declaration forms and assess additional duties, the taxpayer who chooses to contest the additional taxes will be forced to bring suit within the three year period. ${ }^{65}$

Abuses of the rule espoused above are possible. The taxpayer may bring actions to shift deductions taken in previous years into subsequent years (in response to a rise in tax rates), thus making it necessary for the Tax Court to distinguish between real and sham contests. ${ }^{66}$ However, these are abuses which are possible, albeit less likely, under the Dixie Pine Products rule for liabilities contested in the year of accrual, and would pose no new problems for the courts.

60320 U.S. 489 (1943), rehearing denied, 321 U.S. 231 (1944).

01 Id. at 503 .

6243 T.C. 8 (1964).

63 See Treas. Reg. $\$ 1.461-1$ (a) (3) (i) (1957). It should be noted that Anderson and Keller-Dorian hold, by implication, that ordinarily it is not necessary to wait for the statute of limitations on reassessment of a tax to run before accruing and deducting it; absent a contest or other evidence of uncertainty, see Dixie Pine Products Co. v. Commissioner, 320 U.S. 516 (1944), it is sufficiently fixed to accrue and deduct at the end of a year.

64 See Int. Rev. Code or 1954, §6501(a).

65 There is no statutory period within which customs officials must review the declaration forms. Thus, asstuming that: (a) a taxpayer/importer declares and pays one duty on imported goods; (b) deducts additional duties on its federal income tax return for the year of importation; (c) customs officials then wait over three years from the date of the filing of the importer's income tax return to review the declaration forms and assess additional duties; and (d) the importer contests them, then the Commissioner would be barred from disallowing the taxpayer's deductions for the additional duties. However, this sort of situation could be prevented by intra-Treasury cooperation between the Customs Bureau and Internal Revenue Service.

66 See Thorne, Neal \& Co., 13 B.T.A. 490, 494 (1928). 